JOSAR, Vol. 1 No. 1 March, 2018; p-ISSN: 2502-8251; e-ISSN: 2503-1155

Copyrights@ Balitar Islamic University, Blitar-Indonesia https://ejournal.unisbablitar.ac.id/index.php/josar

\title{
PERFORMANCE OF THE LM 386 SOUND SENSOR IN DETECTING FRUIT MATURITY BASED ON SOUND FREQUENCY
}

\author{
Kurnia Paranita KartikaRiyanti \\ Faculty of Informatics Enggeenering Faculty \\ Email :kurnia.paranita@unisbablitar.ac.id
}

\begin{abstract}
The LM 386 module is a sensor that is used to detect sound frequencies. This module consists of amplifiers with low power audio frequencies, has an internal resistor of $135 \mathrm{~K}$ Between feet 1 and 8 feet. In this study a test of the ability of the LM 386 sensor was carried out in capturing the sound vibrations produced by watermelon. This is done to facilitate the watermelon traders in determining the maturity level of the watermelon that will be sold to consumers. The working principle of this tool is to capture the sound vibrations of the watermelon launched on the media, then the sound vibrations of the watermelon will be displayed on the ADC. Then the buzzer is added to the device to detect certain $A D C$ values that indicate mature watermelon and are ready to be sold to consumers. The indication of ripe watermelon is a buzzer sound and an indication of immature watermelon has no buzzer. From the results of this study it is known that for mature and immature watermelon, the $A D C$ reading value is not much different. The mature watermelon value is 26-28 ADC, while the immature watermelon the $A D C$ value produced is 19-25. For raw watermelon the ADC value that is produced is $30-35$. Functionally this sensor can work well, but there are still weaknesses in terms of sensor sensitivity. LM 386 is less sensitive in detecting the exact value of mature and immature watermelons. Lm 386 sensor is more sensitive in detecting the type of sound in the form of a blow.
\end{abstract}

Keyword :Arduino, LM386 Sensor, Maturity Detector, Watermelon

\section{Introduction}

The LM386 module is an amplifier with a low power audio frequency that only requires a small power supply (Dirga, 2016) [1]. The LM386 sound sensor works based on the size of the sound waves that affect the membrane sensor, causing the sensor membrane to move, there is also a small coil behind the membrane that will move up and down (Lestari, 2013) [2]. The LM386 sensor has an internal resistor of $1.35 \mathrm{~K}$ between feet 1 and feet 8 . The LM386 sensor also has another resistor of 15K between pin 1 and pin 5 (Dirga, 2016) [1]. The LM386 sensor is equipped with a microphone to capture sound vibrations.

The LM386 sensor module is often used in research using sound sources. As research by Dewi Lestari and Parwito (2013) with the title Melon Maturity Detection Tool with Sound Sensor and At-Mega 8535 
Microcontroller. This study uses amplitude to determine the level of fruit maturity. The LM386 sensor works based on the size of the sound waves that affect the sensor membrane, causing the sensor membrane to move. On the LM386 sensor there is a small coil behind the membrane that will move up and down. The LM386 sensor has an input voltage of 4-12V. The results of the study revealed that the more mature melon the smaller the amplitude. The amount of amplitude transmitted by mature melons is $22 \%$ to $61 \%$, half melon is $62 \%$ to $65 \%$ and raw melon is $65.2 \%$ to $89 \%$.

The LM386 sensor module has the advantage of low power consumption but produces good output (Syarif, 2017) [3]. The LM386 HW484 series sensor used in this study is equipped with a microphone. The microphone functions on the LM386 series HW-484 sensor module as input sound vibration (input). The next sound vibration will be processed and display the ADC value on the monitor serial. Along with the appearance of the value on the serial monitor, it produces sound output through the buzzer.

In this study, the use of LM 386 sensor was used to read the ADC value of mature, immature and raw watermelons. The ADC value is then applied by fruit traders to help watermelon buyers in the selection of ripe fruit and good consumption. With this tool, fruit buyers can choose and ensure the maturity of the watermelon they buy.This technological advancement makes the buying and selling process run effectively and efficiently

\section{Research Methodology}

\subsection{Time and Place}

The initial research was conducted on June 9, 2018 to collect data on the amount of circulation of the type of watermelon and melon in the Blitar region. This research was carried out in several fruit shops both in Blitar Regency and in Blitar City. The study was conducted using a questionnaire to obtain data on the amount of circulation of the type of watermelon and melon in the Blitar region. Further research is carried out 
by testing tools to be carried out at Balitar Islamic University (UNISBA) until September 2018

\subsection{Potential Problems and Data Collection}

The problem that arises in this study is the difficulty of determining the maturity of watermelons and melons by farmers. These conditions can reduce the quality of the fruit so that it can affect the selling price. Based on the potential problems, data collection on the types of watermelons and melons that were most widely circulated in Blitar Regency and City was carried out as follows:

Table 1 Watermelon Traders Table

\begin{tabular}{|c|l|l|c|c|c|}
\hline \multirow{2}{*}{ No } & \multirow{2}{*}{ Fruit store } & \multicolumn{4}{|c|}{ Watermelon type } \\
\cline { 3 - 6 } & & RS & RNS & YS & YNS \\
\hline 1 & BimaFruit store & & $\sqrt{ }$ & & \\
\hline 2 & TohaFruit store & & $\sqrt{ }$ & & \\
\hline 3 & Ridho Fruit store & & $\sqrt{ }$ & & \\
\hline 4 & LodoyoFruit store & & $\sqrt{ }$ & & \\
\hline
\end{tabular}

Based on Table1, it can be explained "RS" for the type of "Redseeded" watermelon, "RNS" for the type of "Red Seedless" watermelon meat, "YS" for the type of watermelon "Yellow Seed", "YNS" for the type of meat watermelon Seedless Yellow ". The conclusion from table 1 is that the most widely distributed watermelon species in the Blitar region are seedless red flesh watermelon.

\subsection{Need Analysis}

The details of the tools and materials needed to assemble or assemble a fruit maturity detector. The LM386 sensor module used in this study is the HW-484 series as shown in the following figure 1 : 


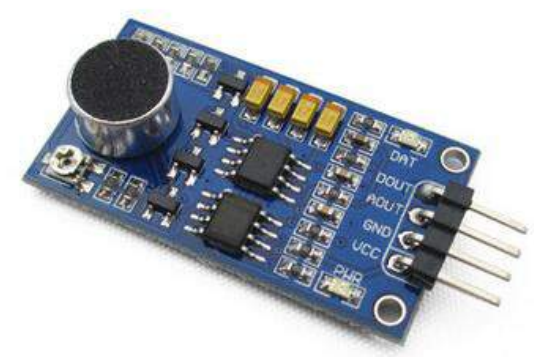

Figure 1 LM386 Series HW-484 Sensor Module

There are several pins on the LM386 with the following information:

1. Pin $A 0$, connected with Analog Pin (AO-A5) on Arduino UNO

2. Pin $\mathrm{G}$, connected to negative voltage or ground on Arduino UNO

3. Pin + , connected with positive voltage or 5 Volt VCC on Arduino UNO

4. Pin D0, connected with Digital Pin (0 to 13) on Arduino UNO

Fruit launcher design like the figure 2. a launcher made of wood with a height of about $50 \mathrm{~cm}$ and a length of skating of $120 \mathrm{~cm}$ long fruit.

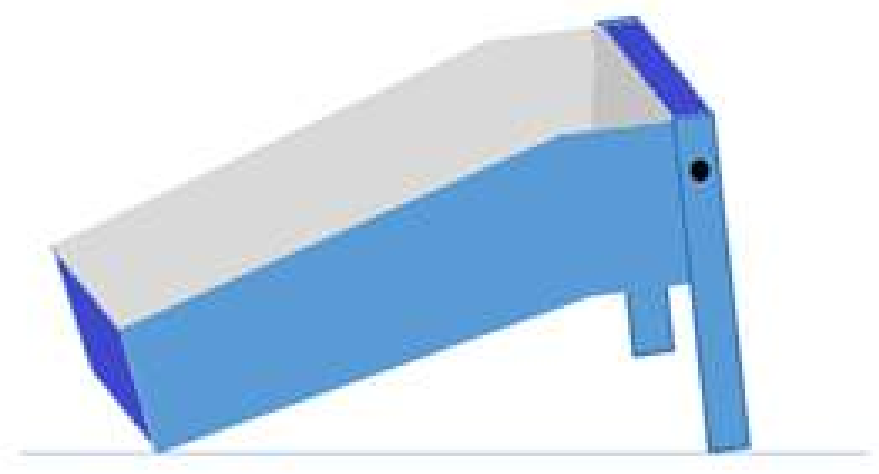

Figure 2fruit slide design

\subsection{Block Diagram}

The following figure is a research block diagram:

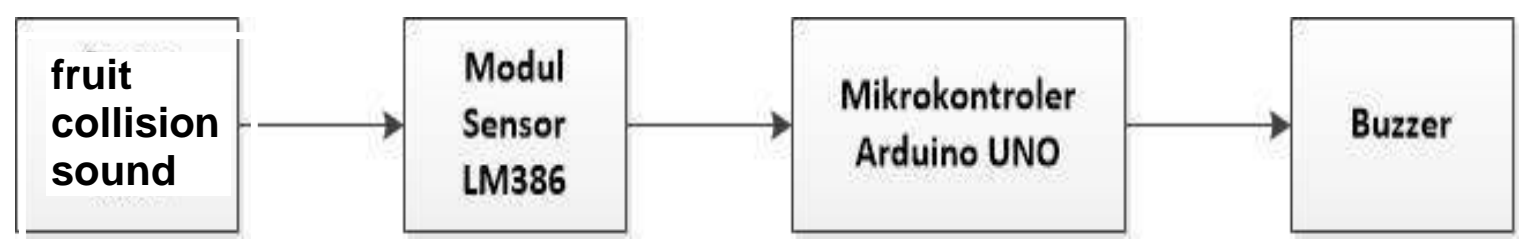

Figure 3Block Diagram of System 
JOSAR, Vol. 1 No. 1 March, 2018; p-ISSN: 2502-8251; e-ISSN: 2503-1155

Copyrights@ Balitar Islamic University, Blitar-Indonesia https://ejournal.unisbablitar.ac.id/index.php/josar

From the block diagram it can be seen that the source comes from the sound of the watermelon collision on the tool. The collision sound is captured by the LM 386 sensor and forwarded to the Arduino UNO microcontroller. Then if the watermelon detected is mature, the buzzer sounds $2 x$ and if the watermelon is still raw, the buzzer reads $1 x$.

\subsection{Flowchart}

Next is the flow of the program to detect the maturity of watermelon fruit.The process starts from the initialization of the components that become the input and output tools. After that, the watermelon was launched, from the microcontroller to process the ADC results that were released which produced a thump sound. If the ADC value shows the number 13-28 then the buzzer will sound $2 x$, and if the ADC value is less than 13 then the buzzer will sound $1 x$ stating that the watermelon is immature.

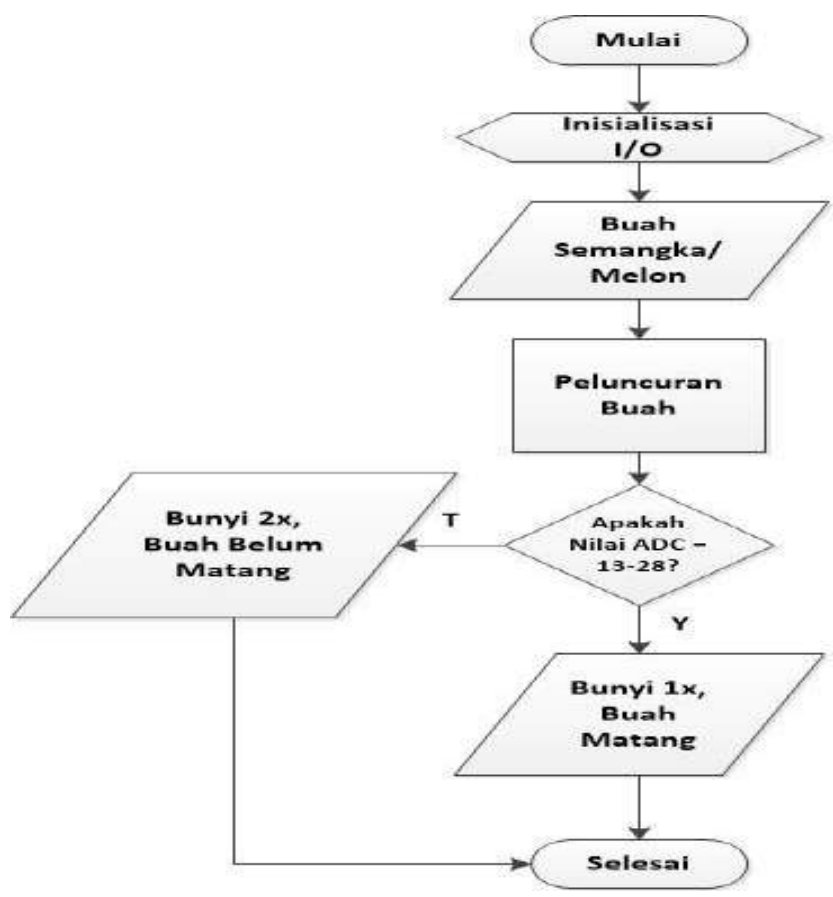

Figure 4 Flowchart of System 


\section{Results and Discussion}

\subsection{Component testing}

Testing each component is done to find out whether each component can be used. The first test is the Arduino UNO test. The test results show the pins on the Arduino UNO can function properly. The test was also successfully carried out by connecting Arduino UNO with other components.

The initial testing of the buzzer is done manually using a series of cables and batteries to ensure the buzzer is functioning. After ascertaining in manual testing, then testing is carried out using the Arduino UNO circuit with the program that has been entered into the Arduino application.

The LM386 sensor test was successfully carried out using the LM386 HW-484 series sensor module. The LM386 HW-484 series sensor module is less sensitive in distinguishing mature watermelon and is not too ripe because the $A D C$ value doesn't change much. Whereas in raw watermelons the ADC value is greater than 40 .

\subsection{Detector Testing}

Tests were carried out several times to determine the maximum results by approaching the LM386 sensor module with sound vibration sources with the results of the HW-484 series LM386 sensor module less sensitive to sound vibrations. Test results with sound vibration sources as shown in table 2 below:

Table 2 Testing with Sound Vibration Source

\begin{tabular}{|c|c|c|c|}
\hline No & Fruit Types & Number of Trial & ADC value \\
\hline \multirow{3}{*}{1} & \multirow{3}{*}{ Ripe Watermelon } & 1 & 27 \\
\hline & & II & 27 \\
\hline & & III & 26 \\
\hline \multirow{3}{*}{2} & \multirow{3}{*}{ Immature Watermelon } & I & 20 \\
\hline & & II & 19 \\
\hline & & III & 19 \\
\hline
\end{tabular}


JOSAR, Vol. 1 No. 1 March, 2018; p-ISSN: 2502-8251; e-ISSN: 2503-1155

Copyrights@ Balitar Islamic University, Blitar-Indonesia https://ejournal.unisbablitar.ac.id/index.php/josar

\begin{tabular}{|c|c|c|c|}
\hline \multirow{3}{*}{3} & \multirow{3}{*}{ Raw Watermelon } & I & 30 \\
\cline { 3 - 4 } & \multirow{2}{*}{ Ray } & II & 34 \\
\cline { 3 - 4 } & III & 32 \\
\hline
\end{tabular}

Based on table 2 it is known that sensors are not too sensitive to sound vibrations. The ADC value produced by raw watermelon ranges above 30, while for mature watermelon and not yet mature enough the value is not too different. The range of ADC values is 20 to 28 .

\section{Conclusion and Suggestion}

\subsection{Conclusion}

The test results, the LM386 series HW-484 sensor is quite sensitive to vibrations caused by fruit collisions. The results of testing for mature watermelon and not yet mature have not much stability (in the range of 20 28). As for the raw watermelon ADC value is above 30 .

\subsection{Suggestion}

Based on the implementation and testing submitted by the author, it shows that the fruit maturity detector using the Arduino UNO and LM386 sensors is still far from perfection. Suggestions can be given as follows:

1. We recommend using a product design that is more effective and practical in its use.

2. Using more sophisticated fruit knockers in future research.

3. Using various types of fruit in future studies.

4.Using tool components that are more assured of their use and sensitivity, in this case are aimed primarily at the LM386 sensor.

The results of detecting fruit maturity should be added to the LCD to find out how long the fruit is in ripe condition 
JOSAR, Vol. 1 No. 1 March, 2018; p-ISSN: 2502-8251; e-ISSN: 2503-1155

Copyrights@ Balitar Islamic University, Blitar-Indonesia https://ejournal.unisbablitar.ac.id/index.php/josar

\section{References}

[1] Dirga. 2016. Lemari Penyimpanan Berbicara Berbasis Mikrokontroller. Skripsi. Sains dan Teknologi, Teknik Elektro, Universitas Sanata Dharma

[2] Lestari, Dewi., danPrawito. 2013. AlatDeteksiKematanganBuah Melon dengan Sensor SuaradanMikrokontroller At-Mega 8535. Depok: Jurnalllmiah Elite Elektro. Vol. 4 No. 1:47-54.

[3] Syarif. 2017. Rangkaian Audio Amplifier Menggunakan IC LM386. http://syarif-projects.blogspot.com/2017/10/rangkaian-audio-amplifierdengan-ic.html Diakses tanggal 10 Oktober 2018 